\title{
PERFORMANCE OF A SMALL DRIP IRRIGATION SYSTEM POWERED BY SOLAR PHOTOVOLTAIC FOR CORN PRODUCTION
}

\author{
A. M. Okasha ${ }^{1}$
}

\section{ABSTRACT}

Application of solar energy with modern irrigation systems is essential to irrigate soil for agricultural crops production.

A field experiment was conducted in research farm, faculty of agriculture, Kafr El-Sheikh Governorate, Egypt during summer season 2014/2015 to study the performance of solar photovoltaic with submersible pump and different lateral drip lines, on corn (Zea mays L.) yield and irrigation water use efficiency under clayey soil.

The treatments were three drip lateral lines (T-tape, Eva-Flow and Flag dripper) and three low pressure levels $(1,1.5$ and $2 \mathrm{~m}$ ) with direct operation of solar photovoltaic without battery storage and under direct insolation. The parameters were output power, photovoltaic efficiency, pump discharge, total dynamic head, hydraulic power, subsystem efficiency flow ratepressure, coefficients of manufacturer's variation, emission uniformity, Christiansen uniformity coefficient, distribution uniformity, corn yield and irrigation water use efficiency.

The important results indicated that:

- Generally, output power increased by increasing of solar radiation intensity but photovoltaic efficiency as general trend was decreased.

- The optimum values were $2.22 \mathrm{~m}, 18.35 \mathrm{~W}$ and $51 \mathrm{l} / \mathrm{min}$ for total dynamic head, hydraulic power and discharge, respectively.

- The highest value of emitter flow rate was $6.44 \mathrm{l} / \mathrm{h}$ which achieved at operating pressure head of $2 \mathrm{~m}$, pump discharge of $41 \ell / \mathrm{min}$, hydraulic power of $17.71 \mathrm{~W}$ and output power from module of $62 \mathrm{~W}$ for T-tape.

- The maximum value of subsystem efficiency was $61.38 \%$ at total dynamic head of $1.04 \mathrm{~m}$ and maximum of pump discharge was $82 \mathrm{l} / \mathrm{min}$.

- The minimum value of flow rate variation was $12.54 \%$ at 1 m operating pressure head and Eva-Flow drip line system

\footnotetext{
${ }^{1}$ Asst. Prof. Agric. Eng. Dept., Faculty of Agric, Kafrelsheikh University, Egypt.
} 
- The highest value of DU was $94.53 \%$ that obtained at Eva-Flow drip system and $1 \mathrm{~m}$ operating pressure head.

- The greatest values of corn yield and IWUE were $0.833 \mathrm{~kg} / \mathrm{m}^{2}$ and $1.71 \mathrm{~kg} / \mathrm{m}^{3}$, respectively, by application of Eva-Flow system at $1 \mathrm{~m}$ operating pressure head.

\section{INTRODUCTION}

T gypt has the land of small areas, especially in the Delta region north of the country. These regions (a small area) caused by the establishment of roads, canals and drains. Modern irrigation systems applications have become essential to the irrigation water because of the deficit, which is increasing day by day due to population growth rate. Pande et al (2003) designed and developed a solar photovoltaic (PV) pump operated drip irrigation system for growing orchards in arid region considering different design parameters like pumps size, water requirements, the diurnal variation in the pressure of the pump due to change in irradiance and pressure compensation in the drippers. The system comprising a PV pump with $900 \mathrm{~W}_{\mathrm{p}} \mathrm{PV}$ array and $800 \mathrm{~W}$ dc motor-pump mono-block, micro filter, main and sub-mains and three open-able low-pressure compensating drippers on each plant was field tested. The emission uniformity was observed to be $92-94 \%$ with discharge of $3.8 \mathrm{l} / \mathrm{h}$ in the pressure range of $70-100 \mathrm{kPa}$ provided by the pump and thus the system could irrigate some 1 ha area within $2 \mathrm{~h}$. Williamson (2006) used a solar powered pumping system enables automated control of irrigation timing and water levels. The drip component of the irrigation system would provide precision application of water, thus ensuring a decrease in water loss from wind and evaporation. The long-term advantages would be lower energy operating costs and savings in water use. Abdolzadeh and Ameri (2009) reported that photovoltaic (PV) water pumping is one the most typical PV applications in developing countries and has the potential to become a major criterion for social and economic development. Photovoltaic cells are the heart of photovoltaic water pumping system so that any changes in the cell's power will affect the photovoltaic water pumping system performance. Egyptian-German Private Sector Development Programme (2010) 
indicated that according to the 1991 Egyptian Solar Radiation Atlas, the country averages between 5.4 and more than $7.1 \mathrm{kWh} / \mathrm{m}^{2}$ of annual daily direct solar radiation, from north to south. The annual direct normal solar irradiance ranges from 2,000 to $3,200 \mathrm{kWh} / \mathrm{m}^{2}$, rising from north to south, with a relatively steady daily profile and only small variations in resource. Karimi and Gomrokchi (2011) found that the highest average grain yield of corn was $12.9 \mathrm{t} / \mathrm{ha}$ while the treatment was drip irrigation at level of $120 \%$ water requirement in a two-row planting pattern and crop density equal to 75000 plants/ha. Also, the highest water use efficiency (WUE) was obtained $1.96 \mathrm{~kg} / \mathrm{m}^{3}$ at the same treatment, while the lowest was found in drip irrigation at a level of $80 \%$ water requirement in a two row planting pattern and crop density equal to 75000 plants $/$ ha as $0.82 \mathrm{~kg} / \mathrm{m}^{3}$. Parida et al (2011) showed that global environmental concerns and the escalating demand for energy, coupled with steady progress in renewable energy technologies, are opening up new opportunities for utilization of renewable energy resources. Solar energy is the most abundant, inexhaustible and clean of all the renewable energy resources till date. The power from sun intercepted by the earth is about $1.8 \times 10^{11} \mathrm{MW}$, which is many times larger than the present rate of all the energy consumption. Photovoltaic technology is one of the finest ways to harness the solar power. Mandal and Naskar (2012) established the performance of a solar photovoltaic pumping system of two 35 watt solar modules. Also, calculated the solar radiation over six month (November to April) for covering all the seasonal solar radiation during 6-7hrs. It can be observed that as the discharge pressure increases the efficiency also increases. The efficiency of the system varies from a low value of $1.55 \%$ at zero discharge pressure to almost $10 \%$ at $\mathrm{kg} / \mathrm{cm}^{2}$ discharge pressure. The system efficiency increases with system output up to a certain value, then droops with further increase in output. Foster and Cota (2014) said that solar power is a natural and symbiotic choice for water pumping. It is one of the most economically attractive solar energy applications with direct drive PV systems often providing decades of reliable service. There is a good match between seasonal solar resource and seasonal water needs. Photovoltaic water pumping (PVWP) systems can meet a wide range of needs and are relatively simple, reliable, cost competitive, and 
low maintenance. Reca et al (2016) explained that solar energy has a very high potential in Mediterranean areas, as its climate is characterized by a high number of sunlight hours. For this reason, the irrigation of many crops in these areas with photovoltaic energy systems is increasingly gaining interest.

Therefore the importance of this research, involving performance of solar photovoltaic with submersible pump and studying the effect of emitters' drip irrigation types, on corn (Zea mays L.) yield and irrigation water use efficiency under clayey soil.

\section{MATERIAL AND METHODS}

\subsection{Experimental site}

The experimental work was conducted during summer growing season 2014/2015 in Research Farm, Faculty of agriculture, Kafr El-Sheikh Governorate, Egypt that located at $31^{\circ} 6^{\prime} \mathrm{N}$ latitude, $30^{\circ} 50^{\prime} \mathrm{E}$ longitude and altitude $6 \mathrm{~m}$. The performance of PV-module with submersible pump and select of drip irrigation lines parameters for producing corn crop of triple-hybrid 324 variety in a small-scale area $(30 \times 16.8) \mathrm{m}$. The average values of particle size distribution, bulk density $\left(\rho_{b}\right)$, field capacity (F.C), available water (A.W) and permanent wilting point (P.W.P) for experimental soil is shown in Table1.

Table1: Soil physical analysis of experimental site.

\begin{tabular}{|c|c|c|c|c|c|c|c|c|}
\hline $\begin{array}{c}\text { Soil } \\
\text { depth } \\
\mathbf{c m}\end{array}$ & \multicolumn{2}{|c|}{ Particle size distribution } & \multirow{2}{*}{ Soil texture } & F.C\% & P.W.P\% & A.W\% & $\rho_{\mathrm{b}}, \mathbf{g} / \mathbf{c m}^{\mathbf{3}}$ \\
\cline { 2 - 9 } & $\begin{array}{c}\text { Silt, } \\
\mathbf{\%}\end{array}$ & $\begin{array}{c}\text { Clay, } \\
\mathbf{\%}\end{array}$ & & & & & \\
\hline $0-15$ & 18.52 & 26.17 & 55.32 & Clay & 43.21 & 22.40 & 23.81 & 1.22 \\
\hline $15-30$ & 22.04 & 26.54 & 51.43 & Clay & 40.58 & 21.40 & 19.19 & 1.25 \\
\hline $30-45$ & 19.72 & 27.62 & 52.67 & Clay & 38.14 & 22.34 & 15.80 & 1.30 \\
\hline $45-60$ & 20.51 & 27.33 & 52.17 & Clay & 36.94 & 21.81 & 15.14 & 1.36 \\
\hline
\end{tabular}

\subsection{System installation and experimental treatments}

Irrigation system components consisted of Solar PV-module, DCsubmersible pump, screen filter, flow-meter, manometer tube and control valves. The main line was elastic hose with $32 \mathrm{~mm}$ outer diameter (OD) to transfer the water from the pump to the manifold pipe made from solid 
PE with $25.4 \mathrm{~mm}$ outer diameter which connected to lateral drip lines of $30 \mathrm{~m}$ length. Seeds of corn were planted on $1^{\text {st }}$ of June by the manual method at $3-5 \mathrm{~cm}$ soil depth, $60 \mathrm{~cm}$ row spacing and $20 \mathrm{~cm}$ on the rows. It was harvested on $23^{\text {rd }}$ of October by handily methods. The experimental field of treatments were designed as a split plot as shown in Figure 1.

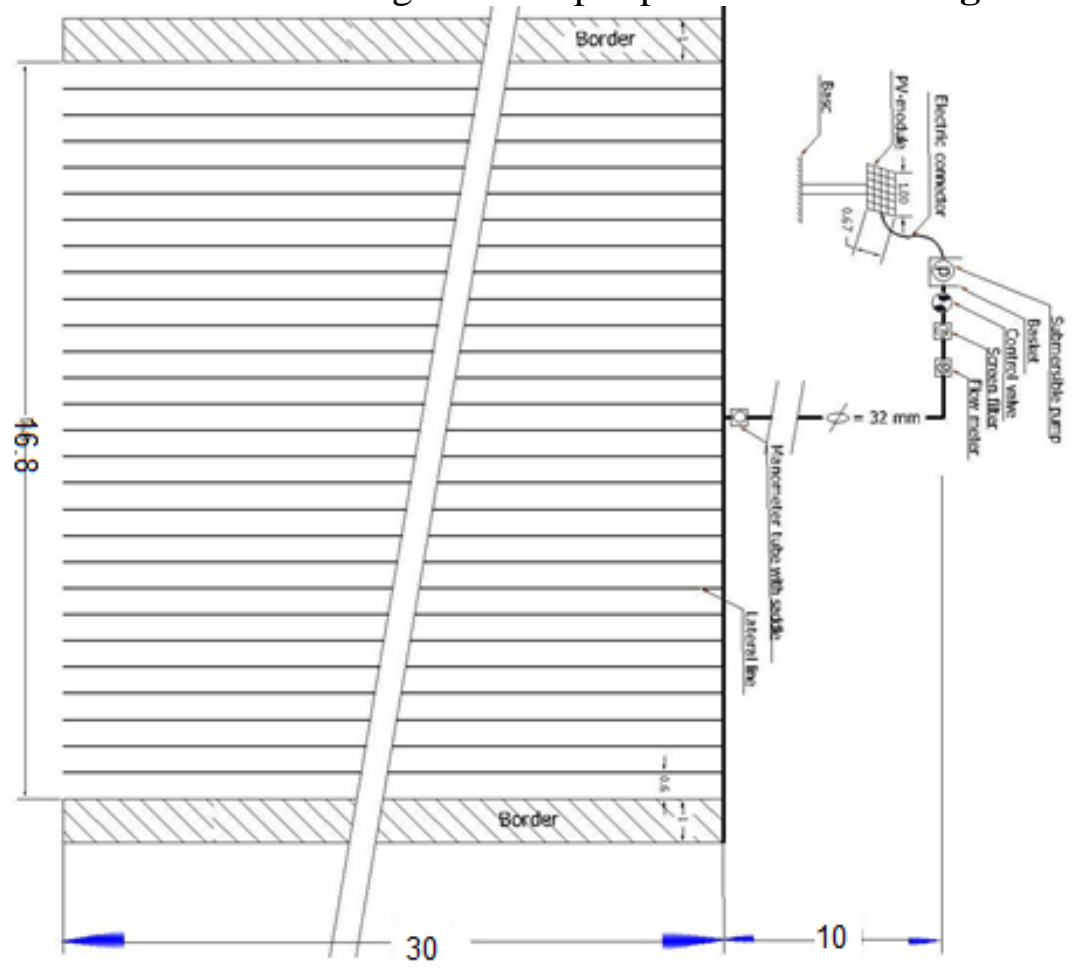

Figure 1: Layout of experimental field

The irrigation system was operating the by direct solar radiation from 8 to 10 A.M, 10 to 12 P.M and 3 to 5 P.M agree with operating pressure heads $(1,1.5$ and $2 \mathrm{~m})$ as main plots and three different drip lateral lines (T-Tape, Eva-Tape and Flag-Drip) represent a sub-main plots with three replications. The parameters were input power (direct operation), output power, hydraulic power output, PV panel efficiency, subsystem efficiency, flow rate- pressure relationship, flow rate variation of emitter, coefficients of manufacturer's variation, emission uniformity, Christiansen uniformity coefficient, distribution uniformity, maize characteristics (height, weight of 100 grain and yield of corn) and irrigation water use efficiency. Routine operations for maize service were 
carried out on time, e.g. control of pests and diseases, fertilization and weeding according to applied recommendations.

\subsection{Solar photovoltaic module and submersible pump specifications}

The specification of solar module and submersible pump are presented in Table2.

Table 2: A solar module and submersible pump specification.

\begin{tabular}{|c|c|c|c|c|c|c|c|}
\hline \multicolumn{8}{|c|}{ Photovoltaic module specifications } \\
\hline \multicolumn{4}{|c|}{ Max-Power $\left(\mathrm{P}_{\mathrm{m}}\right)$} & \multicolumn{4}{|c|}{$100(\mathrm{~W})$} \\
\hline \multicolumn{4}{|c|}{ Max-Power Voltage $\left(\mathrm{V}_{\mathrm{m}}\right)$} & \multicolumn{4}{|c|}{$17.5(\mathrm{~V})$} \\
\hline \multicolumn{4}{|c|}{ Max-Power Current $\left(\mathrm{I}_{\mathrm{m}}\right)$} & \multicolumn{4}{|c|}{$5.71(\mathrm{~A})$} \\
\hline \multicolumn{4}{|c|}{ Open circuit voltage $\left(\mathrm{V}_{\mathrm{OC}}\right)$} & \multicolumn{4}{|c|}{$21.9(\mathrm{~V})$} \\
\hline \multicolumn{4}{|c|}{ Number of cells } & \multicolumn{4}{|l|}{36} \\
\hline \multicolumn{4}{|c|}{ Short circuit current $\left(\mathrm{I}_{\mathrm{sc}}\right)$} & \multicolumn{4}{|c|}{$6.09(\mathrm{~A})$} \\
\hline \multicolumn{4}{|c|}{ Dimension $(\mathrm{mm})$} & \multicolumn{4}{|c|}{$1066 \times 674 \times 35$} \\
\hline \multicolumn{8}{|c|}{ Submersible pump specifications } \\
\hline Item & GPH & Volts & Port & Draw & Fuse & Dimensions & Lbs \\
\hline 02 & 1500 & 12 & $11 / 8^{\prime \prime}$ & $4.8 \mathrm{~A}$ & $9 \mathrm{~A}$ & $6 "$ x 4 1/4" & 4 \\
\hline
\end{tabular}

\subsection{Lateral lines specification}

Three different lateral lines were used in experimental field, as follows:

1- Eva-flow tape (Eva-TAPE), distance between drip holes is $2.5 \mathrm{~cm}$ and equipped with built-in filter, where its perforated side in downward position for drip.

2- Lateral drip tapes (T-TAPE) of PE with $16 \mathrm{~mm}$ inner diameter (ID), $10 \mathrm{~cm}$ spacing between emitters.

3- Drip line with flag emitters (Flag-Drip), and distance between drippers is $20 \mathrm{~cm}$.

\subsection{Measuring Instruments}

Digital pyranometer, multimeter, compass, digital thermometer, metal meter, flowmeter and stop watch.

\subsection{Estimation of water requirements and irrigation application}

Water requirements were computed for irrigating corn based on CROPWAT 8 program (Allen, et al. 1998) as shown in Table 3. Field efficiencies were used as $85 \%$ for drip irrigation. (Irmak et al 2011). 
Applied water before planting and first irrigation during initial plant stage were used, therefore irrigation frequencies were every 3 days. The applied irrigation was terminated 20/10/2015.

Table 3: Maize water requirement calculation

\begin{tabular}{|c|c|c|c|c||}
\hline Date & $\begin{array}{c}\text { Day } \\
\text { from } \\
\text { planting }\end{array}$ & Plant stage & Kc & Actual Evapotranspiration, \\
ETc, mm
\end{tabular}

\subsection{Determination of input and output power to the irrigation system}

The insolation to the PV array gives the input power to the system and output power by using equations as follows:

$$
\begin{aligned}
& P_{i n}=I_{n s} \times A \ldots \\
& P_{\text {out }}=V_{o c} \times I_{s c}
\end{aligned}
$$

\section{Where :}

$\mathrm{P}_{\text {in }}$ :- input power, $\mathrm{W}$

$\mathrm{P}_{\text {out }}$ :-output power, W

$\mathrm{I}_{\mathrm{ns}}$ :- insolation, $\mathrm{W} / \mathrm{m}^{2}$

A :- solar module area, $\mathrm{m}^{2}$

$\mathrm{V}_{\text {oc }}$ :- open circuit voltage, $\mathrm{V}$

$\mathrm{I}_{\mathrm{sc}}$ :- short circuit current, A

\subsection{The hydraulic power output}

The hydraulic power output of the pump is the power required to lift a volume of water through a given head:

$$
P_{h}=\rho \times g \times Q \times H .
$$

Where:

$\mathrm{P}_{\mathrm{h}}$ :- hydraulic power output of the pump, Watt 
$\rho:-$ water density, $(1000) \mathrm{kg} / \mathrm{m}^{3}$

$\mathrm{g}:-$ acceleration of gravity, $(9.81) \mathrm{m} / \mathrm{s}^{2}$

Q:- water discharge, $\mathrm{m}^{3} / \mathrm{s}$

$\mathrm{H}$ :- total pumping head, $\mathrm{m}$

\subsection{System efficiency}

a) PV panel efficiency $\left(\eta_{\text {panel }}\right)$ is the measure of how efficient the PV panel is in converting sunlight to electricity. The efficiency was calculated by the following equation:

$$
\eta_{\text {panel }}=\frac{P_{\text {out }}}{P_{\text {in }}}=\frac{V_{O C} \times I_{S C} \times F F}{I_{n s} \times a} \times 100
$$

Where:

FF:- fill factor which equals about 0.67 for $\mathrm{Si}$.

b) Subsystem efficiency $\left(n_{\mathrm{s}}\right)$ is the efficiency of the entire system components:

$$
\mathrm{n}_{\mathrm{s}}=\left(\mathrm{P}_{\mathrm{h}} / \mathrm{P}_{\text {output }}\right) \times 100, \%
$$

\subsection{Frication losses in pipes}

Hazen-Williams equation was used to calculate friction losses as was originally assumed by Wu and Gitlin (1973):

$$
H_{f}=\frac{1.22 \times 10^{10} \times L}{D^{4.87}}\left(\frac{Q}{C}\right)^{1.852}
$$

Where

Q:- discharge, $\ell / \mathrm{s}$

D:- inner diameter of pipe, $\mathrm{mm}$

L:- line pipe length, $\mathrm{m}$

$\mathrm{H}_{\mathrm{f}}$ :- pipe friction loss, $\mathrm{m}$

C:- Hazen-Williams factor and friction factor value of pipes, references have taken $\mathrm{C}=150$.

\subsection{Determination of flow rate- pressure relationship}

The values of emitters' flow rates with operating pressure under experimental field were described by the power curve equation as presented as follow (Keller and Karmeli 1974):

$$
q=k(h)^{x}
$$


Where:

$\mathrm{q}$ :- the emitter flow rate, $\ell / \mathrm{h}$,

$\mathrm{k}$ :- constant of proportionality that characterizes each emitter,

h:- operating pressure head, $\mathrm{m}$ and

$\mathrm{x}$ :-emitter discharge exponent that is characterized by the flow regime.

\subsection{Determination of uniformity of drip line systems}

These measurements were used to determine emission uniformity and application efficiency. For each test, 24 emitters were selected from head, middle and tail ends of drip lines, randomly. Water was collected from outflow emitters per unit time.

\section{a) Flow rate variation of emitter}

Percent flow rate variation of different lateral types were determined by the following equation (Bralts et al. 1982).

$$
q_{\mathrm{var}}=\frac{q_{\max }-q_{\min }}{q_{\max }} \times 100
$$

Where,

$\mathrm{q}_{\text {var:- }}$ emitter flow variation, $\%$,

$\mathrm{q}_{\max }$ :- maximum emitter discharge, $\ell / \mathrm{h}$ and

$\mathrm{q}_{\text {min:- }}$ minimum emitter discharge, $\ell / \mathrm{h}$

\section{b) The coefficients of manufacturer's variation:}

The coefficients of manufacturer's variation describe the quality of the processes which used to manufacture those emission devices. It was computed with the following equation. (Cited from, James 1988)

$$
\mathrm{CV}=\frac{\left(\mathrm{q}_{1+}^{2} \mathrm{q}_{2}^{2}+\cdots+\mathrm{q}_{\mathrm{n}-\mathrm{n}}^{2} \overline{\mathrm{q}}^{2}\right)^{0.5}}{\overline{\mathrm{q}}(\mathrm{n}-1)^{0.5}}
$$

Where:

$\mathrm{CV}$ :- manufacturer's coefficient of variation, dimensionless

$\mathrm{q}_{1}, \mathrm{q}_{2} \ldots \ldots . \mathrm{q}_{\mathrm{n}}$ :- discharge of emission devices, $\ell / \mathrm{h}$,

$\bar{q}$ : average discharge of emission devices tested, $\ell / \mathrm{h}$ and

$\mathrm{n}$ : number of emission devices tested.

c) Emission uniformity: Emission uniformity has been developed for evaluating trickle lateral design and emission device selection and is defined by the following equation. (keller and karmeli, 1974): 


$$
E U=\left(100\left(1.0-\frac{1.27}{\sqrt{N_{e}}} C V\right) \frac{Q_{\text {min }}}{Q_{\text {ave }}}\right.
$$

Where:

EU:- emission uniformity in percent,

$\mathrm{N}_{\mathrm{e}}$ :- number of point source emitters per emission point,

CV:- manufacturer's coefficient of variation,

$\mathrm{Q}_{\text {min:- }}$ the minimum emitter discharge rate in the system, $\ell / \mathrm{h}$ and

$Q_{\text {ave:- }}$ the average or design emitter discharge rate, $\ell / \mathrm{h}$.

d) Christiansen uniformity coefficient: The uniformity of application is evaluated using the Christiansen uniformity coefficient according to the following equation (Christiansen, 1941; ASAE, 2001)

$$
C U=\left[1-\frac{\sum_{i=1}^{i=n}\left|q_{i}-\bar{q}\right|}{\bar{q} \times n}\right] \times 100
$$

Where:

CU:- Christiansen uniformity coefficient,

n:- number of observed emitter or cans,

$\mathrm{q}_{\mathrm{i}}$ :- emitter flow rate, $\ell / \mathrm{h}$, and

$\bar{q}$ :- average discharge of emission devices tested, $\ell / \mathrm{h}$.

e. Distribution uniformity: Distribution uniformity is expressed as a decimal as suggested by Burt et al. (1997).

$$
\mathrm{Du}=100 \times \frac{\mathrm{q}_{\mathrm{lq}}}{\overline{\mathrm{q}}}
$$

Where:

Du: Distribution uniformity, \%

$\mathrm{q}_{\mathrm{lq}}$ : low-quarter average volume amount caught, and

$\bar{q}$ : average amount volume caught.

2.13 Maize characteristics and irrigation water use efficiency (IWUE) At the end of growing season, crop parameters were determined by hand harvesting of 10 ears from every treatment. Height, weight of 100 grain and yield of corn at an average moisture content of $15.5 \%$ wet basis was measured (Yazar et al 1999 and Lauer 2002).

Irrigation water use efficiency was calculated as follows: (James, 1988) 


$$
\text { IWUE }=\frac{\text { Total yield, }\left(\mathrm{kg} / \mathrm{m}^{2}\right)}{\text { Total applied irrigation water }\left(\frac{\mathrm{m}^{3}}{\mathrm{~m}^{2}}\right)}
$$

Where:

IWUE: - irrigation water use efficiency, $\mathrm{kg} / \mathrm{m}^{3}$

Data analyses were carried out using CoStat program for windows.

\section{RESULTS AND DISCUSSION}

\section{1- Performance of solar module and submersible pump.}

The experimental results showed that output power increased by increasing of solar radiation but photovoltaic efficiency as general trend was decreased as shown in Figure 2 due to variation and increasing of module temperatures from $27^{\circ} \mathrm{C}$ to $53.8^{\circ} \mathrm{C}$ were measured on back surface of module while ambient temperatures varied from $25^{\circ} \mathrm{C}$ to $35.9^{\circ} \mathrm{C}$. Most of these results agreed with (Abdolzadeh and Ameri 2008) and (Imara and Eltawil 2006).

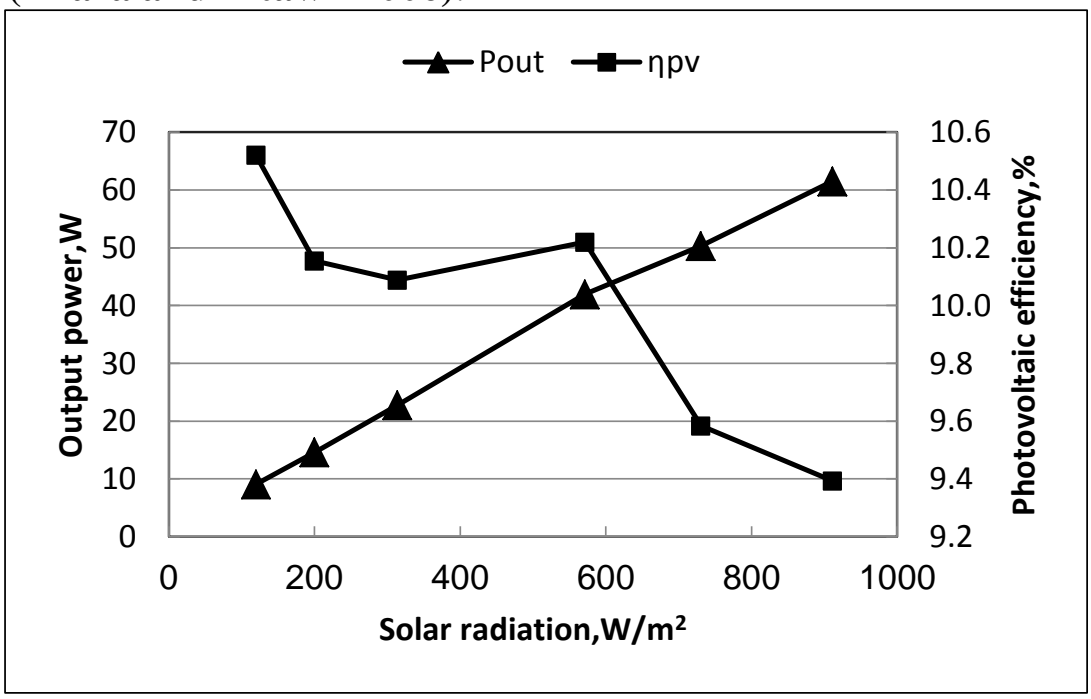

Figure 2: PV module power output and efficiency as affected by solar radiation.

The relationship among the pump discharge $(\mathrm{Q})$, total dynamic head $(\mathrm{H})$ and hydraulic power $\left(\mathrm{P}_{\mathrm{h}}\right)$ or performance of submersible pump during operation is shown in Figure 3. Pump discharge decreased by increasing of total dynamic head. While hydraulic power varied from increment to decreasing. All points were suitable for operating field requirements. The 
optimum values were $2.22 \mathrm{~m}, 18.35 \mathrm{~W}$ and $51 \ell / \mathrm{min}$ for total dynamic head, hydraulic power and discharge, respectively.

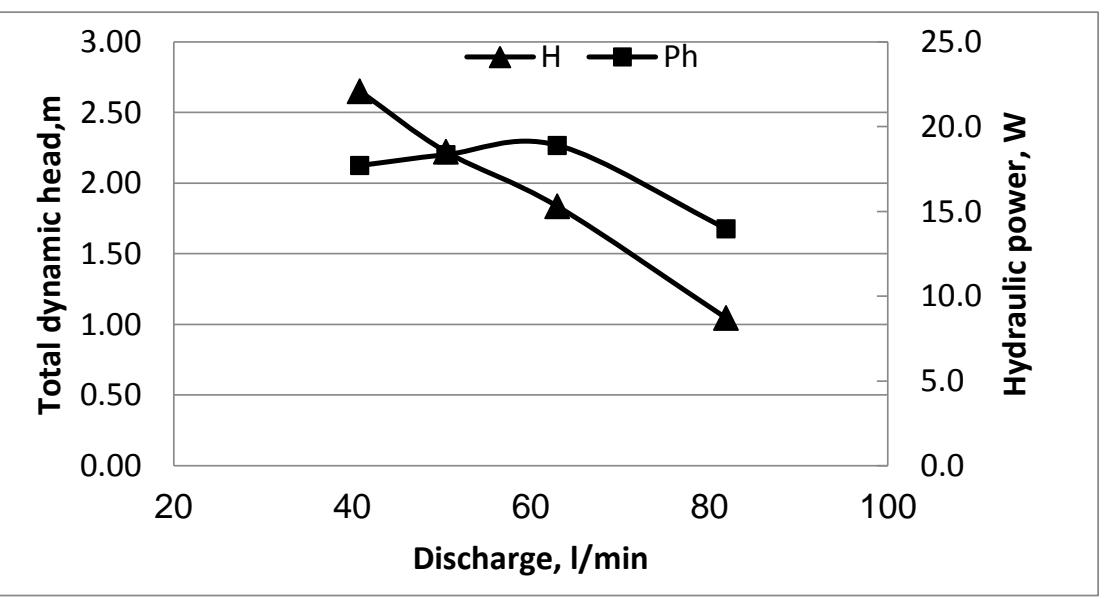

Figure 3: Performance characteristics curve of submersible pump.

\section{Subsystem efficiency $\left(\boldsymbol{n}_{\mathbf{s}}\right)$}

The relationship among discharge( Pump flow rate), total dynamic head and subsystem efficiency is shown in Figure 4. Subsystem efficiency increased $\left(\mathrm{\eta}_{\mathrm{s}}\right)$ by increasing of pump discharge and decreasing of total dynamic head. The maximum value of subsystem efficiency was $61.38 \%$ at total dynamic head of $1.04 \mathrm{~m}$ and maximum pump discharge of 82 $\ell / \mathrm{min}$. The effect of discharge on subsystem efficiency was more effective than the total dynamic head.

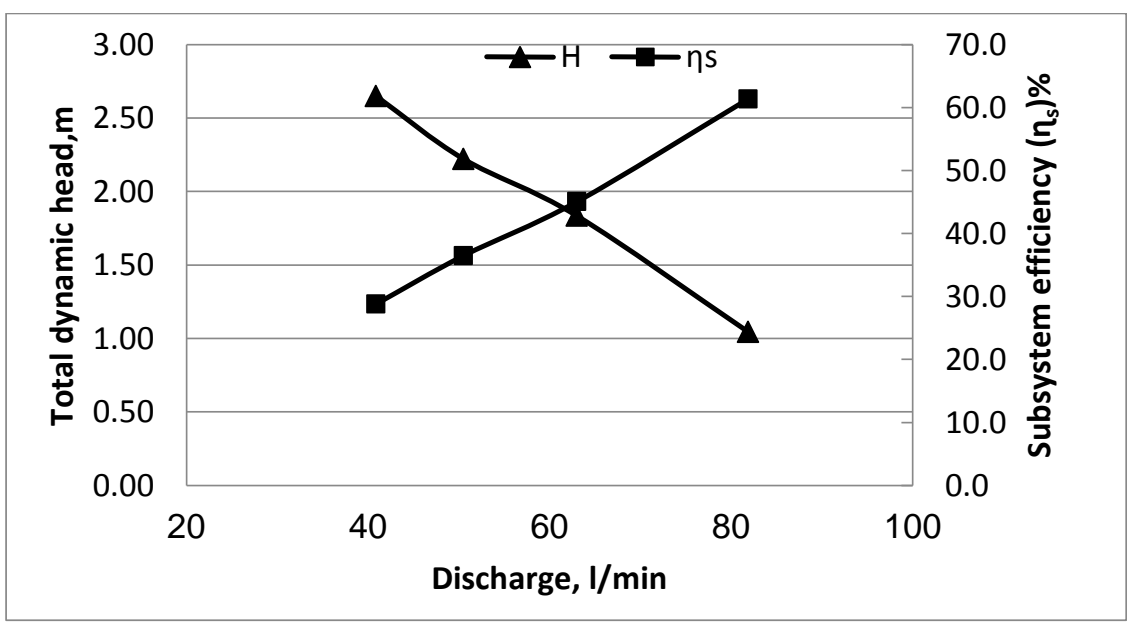

Figure 4. Relationship among discharge( Pump flow rate), total dynamic head and subsystem efficiency. 


\section{3- Performance of different drip lines}

Results presented in Table 4 and Figure 5, indicated that the emitter flow rates increased by increasing of operating pressure head for all drip

Table 4: Emitter flow rate under different operating pressure heads

\begin{tabular}{|c|l|c|c|c|c|}
\hline \multirow{4}{*}{$\begin{array}{c}\text { Emitter } \\
\text { flow rate, }\end{array}$} & \multirow{2}{*}{$\begin{array}{c}\text { Emitter type } \\
\ell / \mathrm{h}\end{array}$} & \multicolumn{3}{|c|}{$\begin{array}{c}\text { Operating pressure } \\
\text { head, }\end{array}$} & $\begin{array}{c}\text { Flow rate(q) - } \\
\text { pressure } \\
\text { (h)relationship }\end{array}$ \\
\cline { 2 - 5 } & T-Tape & 1.00 & 1.50 & 2.00 & \\
\cline { 2 - 5 } & Eva-Tape & 3.59 & 5.02 & 6.44 & $\mathrm{q}=2.0302(\mathrm{~h})^{0.58}$ \\
\cline { 2 - 5 } & Flag-Drip & 2.83 & 3.73 & 4.90 & $\mathrm{q}=2.3176(\mathrm{~h})^{0.38}$ \\
\hline
\end{tabular}

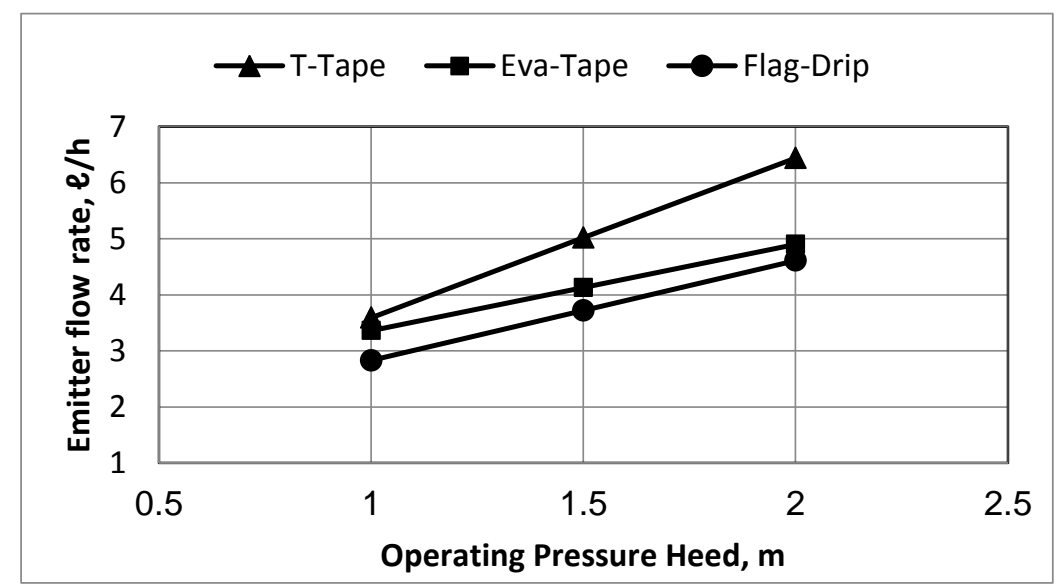

Figure 5. Effect of operating pressure head on emitter flow rate.

lateral line systems. The highest value of emitter flow rate was $6.44 \mathrm{l} / \mathrm{h}$ which achieved at operating pressure head of $2 \mathrm{~m}$, pump discharge of $41 \ell / \mathrm{min}$, hydraulic power of $17.71 \mathrm{~W}$ and output power from module of $62 \mathrm{~W}$ for T-tape with cooperation of the pervious figures. T-Tape and Flag-drip systems were considered as turbulent flow because of exponent values of equations ( $\mathrm{x}$ ) around that 0.5. It found that Eva-Tape was considered as vortex drippers because it was less sensitive of pressure $(\mathrm{x}=0.38)$.

\subsection{Uniformity of drip line systems}

The effect of operating pressure head on flow rate variation, coefficients of manufacturer's variation (C.V), emission uniformity (EU), Christiansen uniformity coefficient (CU), and distribution uniformity (DU) at different emitter line systems are show in Table 5. The effects of operating pressure heads, drip lines and interaction between them were high 
significant at $5 \%$ on all pervious parameters. The minimum value of flow rate variation was $12.54 \%$ at $1 \mathrm{~m}$ operating pressure head and Eva-Flow drip line system. The maximum value of flow rate variation was $42.12 \%$ at $2 \mathrm{~m}$ operating pressure head and Flag-Dripper drip line system. The low $\mathrm{CV}$ indicated good performance of the drip line system according to ASAE (1985) (cited from James 1988). Therefore, the T-Tape had the lowest value of CV (0.068) at operating pressure head of $2 \mathrm{~m}$.

Emission uniformity (EU): The highest value of emission uniformity was $85.95 \%$ by using Eva-Flow system at $1 \mathrm{~m}$ operating pressure head. All presented data of CU were very good. The highest value of CU was achieved by T-Tape drip system at $2 \mathrm{~m}$ operating pressure head. According to Pitts (1997) DU greater than 87\% implied an excellent functioning of the drip system. The present data indicates that, all values of distribution uniformity (DU) were acceptable expect the values of 70.98 and $79.64 \%$ with Flag-Dripper system at operating pressure head of 2 and $1.5 \mathrm{~m}$, respectively. The highest value of DU was $94.53 \%$ that obtained with Eva-Flow drip system and 1m operating pressure head. The highest value of distribution uniformity means good water distributed to different areas in the field.

Table5: Effect of operating pressure heads and type of emitter on $\mathrm{q}_{\mathrm{ver}} \mathrm{CV}$, $\mathrm{EU}, \mathrm{CU}$ and DU at different lateral types.

\begin{tabular}{|c|c|c|c|c|c|c|}
\hline $\begin{array}{c}\text { Operating } \\
\text { pressure } \\
\text { heads, }\end{array}$ & Emitter Type & \multicolumn{5}{|c|}{ Parameter } \\
\cline { 3 - 7 } & & $\mathbf{q}_{\text {ver }} \%$ & $\begin{array}{c}\text { CV, } \\
\text { dimensionless }\end{array}$ & $\mathbf{E U , ~ \% ~}$ & $\mathbf{C U , \%}$ & DU, \% \\
\hline \multirow{3}{*}{$\mathbf{1}$} & T-Tape & 20.59 & 0.122 & 76.30 & 90.83 & 90.33 \\
\cline { 2 - 7 } & Eva-Flow & 12.54 & 0.071 & 85.95 & 94.61 & 94.53 \\
\cline { 2 - 7 } & Flag-Dripper & 14.73 & 0.084 & 83.36 & 93.68 & 93.35 \\
\hline \multirow{3}{*}{$\mathbf{1 . 5}$} & T-Tape & 15.45 & 0.130 & 73.24 & 90.86 & 87.77 \\
\cline { 2 - 7 } & Eva-Flow & 13.81 & 0.078 & 84.41 & 94.25 & 93.63 \\
\cline { 2 - 7 } & Flag-Dripper & 32.37 & 0.191 & 77.82 & 86.43 & 79.64 \\
\hline \multirow{3}{*}{$\mathbf{2}$} & T-Tape & 12.48 & 0.068 & 85.89 & 95.03 & 94.04 \\
\cline { 2 - 7 } & Eva-Flow & 14.77 & 0.083 & 83.24 & 93.93 & 93.00 \\
\cline { 2 - 7 } & Flag-Dripper & 42.12 & 0.264 & 47.17 & 80.66 & 70.98 \\
\hline
\end{tabular}

\subsection{Maize yield and irrigation water use efficiency (IWUE)}

Data listed in Table 6 shows the effect of operating pressure head and drip line systems on some maize parameters, yield and irrigation water use efficiency. The maximum value of plant height was $2.31 \mathrm{~m}$ by using of TTape and $2 \mathrm{~m}$ operating pressure head. The greatest values of mass of 100 
kernels, yield and IWUE were, $35.71 \mathrm{~g}, 0.833 \mathrm{~kg} / \mathrm{m}^{2}$ and $1.71 \mathrm{~kg} / \mathrm{m}^{3}$, respectively by application of Eva-Flow system at $1 \mathrm{~m}$ operating pressure head. These are good values due to less $\mathrm{q}_{\mathrm{var}}$ and greatest values of other uniformity Eva-Flow drip line system. The effect of each of the operating pressure, the type of drip systems and the interaction between them on all the previous indicators were high significant at the $5 \%$ level.

Table 6: Effect of different lateral lines on some of maize crop parameters and irrigation water use efficiency

\begin{tabular}{|c|c|c|c|c|c|}
\hline \multirow{2}{*}{$\begin{array}{l}\text { Operating } \\
\text { pressure } \\
\text { heads, m }\end{array}$} & \multirow{2}{*}{$\begin{array}{c}\text { Emitter } \\
\text { Type }\end{array}$} & \multicolumn{4}{|c|}{ Parameter } \\
\hline & & $\begin{array}{c}\text { Plant } \\
\text { height, } \\
\text { m }\end{array}$ & $\begin{array}{c}\text { Mass of } \\
100 \\
\text { kernels, } \\
\mathrm{g}\end{array}$ & $\begin{array}{l}\text { Yield, } \\
\mathrm{kg} / \mathrm{m}^{2}\end{array}$ & $\begin{array}{l}\text { IWUE, } \\
\mathrm{kg} / \mathrm{m}^{3}\end{array}$ \\
\hline \multirow{3}{*}{1} & T-Tape & 2.00 & 27.54 & 0.643 & 1.32 \\
\hline & Eva-Flow & 2.22 & 30.94 & 0.833 & 1.71 \\
\hline & Flag-Dripper & 2.24 & 27.81 & 0.658 & 1.35 \\
\hline \multirow{3}{*}{1.5} & T-Tape & 2.18 & 27.54 & 0.643 & 1.32 \\
\hline & Eva-Flow & 2.17 & 35.71 & 0.722 & 1.49 \\
\hline & Flag-Dripper & 2.15 & 28.19 & 0.649 & 1.33 \\
\hline \multirow{3}{*}{2} & T-Tape & 2.31 & 32.04 & 0.748 & 1.54 \\
\hline & Eva-Flow & 2.05 & 28.75 & 0.671 & 1.38 \\
\hline & Flag-Dripper & 2.05 & 26.18 & 0.611 & 1.26 \\
\hline
\end{tabular}

\section{CONCLUSIONS}

It has been concluded that:

- Performance of DC-submersible pump with PV-module to lift irrigation water and low pressure achieved important results for subsystem efficiency, maize productivity and irrigation water use efficiency by different lateral drip lines in clayey soil.

- The irrigation water comes out directly from the submersible pump to the irrigation point without storage.

- Utilization of solar energy to produce maize crop became acceptable for small scales under experimental conditions.

\section{REFERANCES}

Abdolzadeh, M. and M. Ameri, (2009). Improving the effectiveness of a photovoltaic water pumping system by spraying water over the front of photovoltaic cells. Renewable Energy, 34(1), 91-9. 
Allen, R. G.; L. S. Pereira; D. Raes and M. Smith (1998). Crop evapotranspiration-Guidelines for computing crop water requirements-FAO Irrigation and drainage paper 56. FAO, Rome, 300(9), D05109.

ASAE. (2001). Test procedure for determining the uniformity of water distribution of center pivot and lateral move irrigation machines equipped with spray or sprinkler nozzles. ANSI/ASAE Standard S436.1, American Society of Agricultural Engineers, St. Joseph, MI.

Bralts, V. F.; I. P. Wu and M. Giltin (1982). Emitter plugging and drip irrigation lateral line hydraulics. Transactions of the ASAE, 25(5), 1274-1281

Burt, C.; A. Clemmens; T. Strelkoff; K. Solomon; R. Bliesner; L. Hardy； T. Howell and D. Eisenhauer (1997). Irrigation Performance Measures: Efficiency and Uniformity. J. Irrig. Drain Eng., 123 : (6) 423-442.

Egyptian-German Private Sector Development Programme, Prospects of the Renewable Energy Sector in Egypt (2010). Focus on Photovoltaics and Wind Energy. Cairo, Egypt.

Foster, R., \& Cota, A. (2014). Solar water pumping advances and comparative economics. Energy Procedia, 57, 1431-1436.

Imara, Z. M. and M. A. Eltawil (2006). Performance of small scale SPV-Powered-drip irrigation system for remote regions. The $14^{\text {th }}$ Annual conference of the MSAE on "Modern Direction in Agricultural Engineering" Organized with Agric. Eng. Dept., Faculty of Agric. Ain Shams Univ., Egypt, November. $22^{\text {nd }}$, Misr J. Ag. Eng. 23(4): 1133-1154.

Irmak, S.; L. Odhiambo; W. Kranz and D. Eisenhauer (2011). Irrigation efficiency and uniformity, and crop water use efficiency. University of Nebraska, Lincoln.

James, L. G. (1988). Principles of farm irrigation systems design. John Wiley and Sons Limited. Page, 277. 
Karimi, M. and A. Gomrokchi (2011). Yield and water use efficiency of corn planted in one or two rows and applying furrow or drip tape irrigation systems in Ghazvin Province, Iran. Irrigation and Drainage, 60(1), 35-41.

Keller J. and D. Karmeli (1974). Trickle irrigation design parameters. Transaction of the ASAE, 17(4): 674-684.

Lauer, J. (2002). Methods for calculating corn yield. Available online: http://corn. agronomy. wisc. edu/AA/pdfs A, 33.

Mandal, R., and Naskar, R. (2012). A Study of Solar Photovoltaic Application in Irrigation System and Its Performance Analysis in Laboratory Scale.International Journal of Advanced Alternative Energy, Environment and Ecology, 1(1), pp-1.14.

Meah, K.; S. Ula, and S. Barrett (2008). Solar photovoltaic water pumping-opportunities and challenges. Renewable and Sustainable Energy Reviews,12(4), 1162-1175.

Pande, P. C.; A. K. Singh; S. Ansari; S. K. Vyas and B. K. Dave (2003). Design development and testing of a solar PV pump based drip system for orchards. Renewable Energy, 28(3), 385-396.

Parida, B.; S. Iniyan and R. Goic (2011). A review of solar photovoltaic technologies. Renewable and sustainable energy reviews, 15(3), 1625-1636.

Pitts, D. J. (1997). Evaluation of micro irrigation systems. South West Florida Research and Education Center, University of Florida.

Reca, J.; C. Torrente; R. López-Luque and J. Martínez (2016). Feasibility analysis of a standalone direct pumping photovoltaic system for irrigation in Mediterranean greenhouses. Renewable Energy, 85, 1143-1154.

Williamson, E. (2006). Solar power water pump studies for small-scale irrigation (Doctoral dissertation, McGill University).

Wu I-P and Gitlin HM (1973). Hydraulics and uniformity for drip irrigation. J Irrig Drain Eng ASCE 99: 157-168.

Yazar, A.; T. A. Howell; D. A. Dusek and K. S. Copeland (1999). Evaluation of crop water stress index for LEPA irrigated corn. Irrigation Science, 18(4), 171-180. 


\section{الملخص العربي \\ أداء نظام الري بالتنقيط بالطاقة الثمسية لإنتاج محصول الذرة \\ د. عبدالعزيز محمد عكاشةة*}

اصبح استخدام الطاقة الثمسية مع انظمة الري الحديث امر جوهريا لري التربة لانتاج المحاصيل الحقلية. تم اجراء تجربة حقلية بمزرعة كلية الزراعة بمحافظة الرية كفر الثيخ خلال

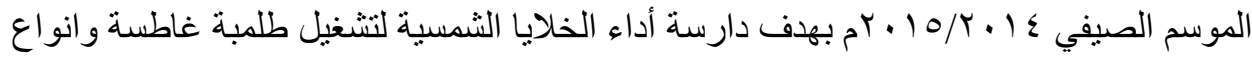
خطوط مختلفة للري بالتنقط علي انتاجية محصول الذرة الثنامية وكفاءة استخدام مياه الري تحت

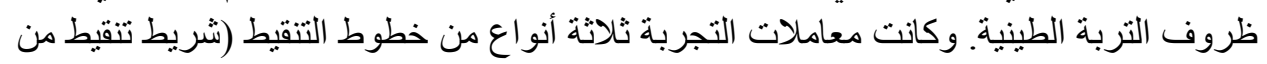

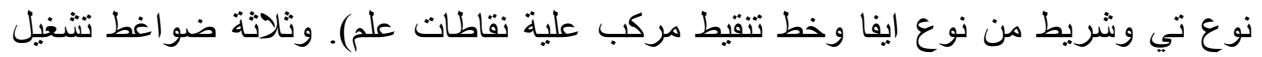

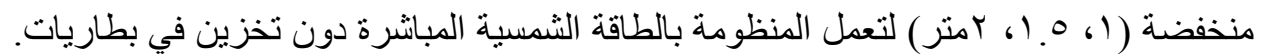

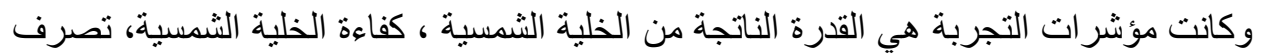

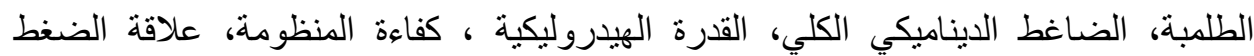
بالتصرف، معاملات الاختلاف للنقاطات، انتظامية التوزيع ، انتاجية الذرة وكفاءة استخدام مياه

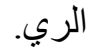

وكاتت اهم النتائج المتحصل عليها كالتالي:-

عموما، تزداد القدرة الناتجة بزيادة شدة الاشتعاع الثمسي ولثئل ولكن كفاءة الخلية الثمسية تميل الي

الانخفاض.

كانت النتائج المثلي المتحصل عليها لكل من الضاغط الديناميكي الكلي، القدرة.

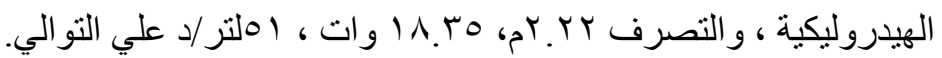

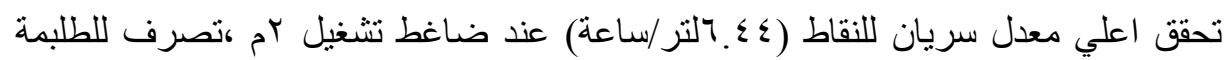

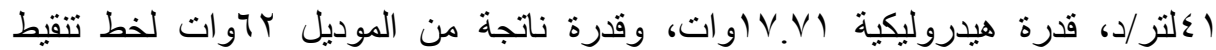

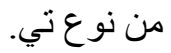

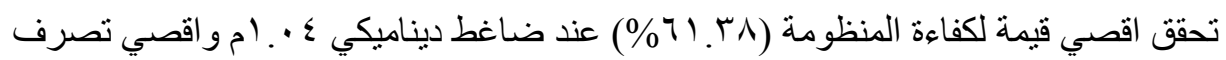

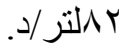
كانت اقل قيمة لاختلاف معدل السريان (ع. Y 1\%) عند تطبيق ضغط تشغيل ام وخط تنقيط من نوع ايفا. تحقق اعلي قيمة لانتظامية التوزيع (به.؟؟\%) باستخدام خط تنقيط من نوع ايفا وضغط تشغيل ام. بتطبيق خط تنقيط من نوع ايفا وضاغط تشغيل ام تم الحصول علي اعلي قيمة لانتاجية الذرة

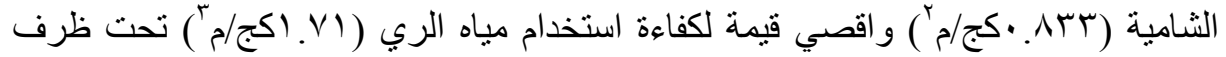

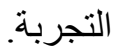

*مدرس الهنسة الزراعيةـ كلية الزراعةـ جامعة كفرالثيخ- مصر. 